\title{
Induction of Flowering by Girdling in Jamun cv. Konkan Bahadoli
}

\author{
P. M. Haldankar ${ }^{1}$, N. V. Dalvi ${ }^{3}$, Y. R. Parulekar ${ }^{1} \&$ K. E. Lawande ${ }^{2}$ \\ ${ }^{1}$ Department of Horticulture, College of Agriculture, Dr. B. S. Konkan Krishi Vidyapeeth, Dapoli-415712, \\ Dist.-Ratnagiri, (M.S.), India \\ ${ }^{2}$ Vice Chancellor, Dr. B. S. Konkan Krishi Vidyapeeth, Dapoli-415712, Dist.-Ratnagiri, (M.S.), India \\ ${ }^{3}$ Agriculture Research Station, Palghar, Dist. Thane, (M.S.) India \\ Correspondence: P. M. Haldankar, Department of Horticulture, College of Agriculture, Dr. B. S. Konkan Krishi \\ Vidyapeeth, Dapoli-415712, Dist.-Ratnagiri, (M.S.), India. Tel: 91-942-180-9721. E-mail: \\ parag5663@rediffmail.com, paraghaldankar@yahoo.co.in
}

\author{
Received: March 23, 2014 Accepted: May 13, 2014 Online Published: May 21, 2014 \\ doi:10.5539/jps.v3n2p45 URL: http://dx.doi.org/10.5539/jps.v3n2p45
}

\begin{abstract}
Jamun (Syzygium cuminii) is an underexploited fruit crop gifted with abundant nutritional and medicinal values. In spite of its greater economic value, farmers are reluctant to establish jamun orchards as flowering is the major constraint. The prebearing age of jamun is fairly long even in grafts. It takes about 6 to 7 years for commencement of flowering and many times this period is extended up to 10 years. An experiment was therefore undertaken under two distinct locations having different weather conditions to study the efficiency of girdling for induction of flowering in jamun under Maharashtra conditions. The experiment was conducted in Randomized Block Design with five treatments viz. $T_{1}$ - Deep cut on secondary branches, $T_{2}-$ Deep cut on tertiary branches, $\mathrm{T}_{3}$ - Removal of $3 \mathrm{~mm}$ bark on secondary branches, $\mathrm{T}_{4}$ - Removal of $3 \mathrm{~mm}$ bark on tertiary branches and $\mathrm{T}_{5}$ - Control (No girdling). Results indicated that girdling was beneficial in jamun for induction of flowering, greater flowering intensity, more number of flowers and fruits per branchlet, reduced period from flowering to harvesting and higher yield as compared to control plants. Tertiary branches were found to be more appropriate location for girdling than secondary branches. Girdling with deep cut without removal of bark was more beneficial than the removal of bark. $T_{2}$ was the best treatment of girdling in jamun.
\end{abstract}

Keywords: jamun, Syzygium cuminii, secondary branches, tertiary branches, girdling, flowering, fruitset, yield

\section{Introduction}

Jamun (Syzygium cuminii) is an underexploited fruit crop possessing abundant nutritional and medicinal values. It is indigenous to India and also known as Indian black cherry or black plum (Bajpai \& Chatuevedi, 1985). It is hardy crop and cultivated in most of the parts of India from Uttar Pradesh to Tamilnadu. In Konkan region of Maharashtra, jamun is traditionally cultivated. However, its cultivation is not in organized form. The flowers in jamun are generally born in axils of one season old branch let. The floral buds assume a club shaped appearance. The flowering starts in first week of March and continues up to the end of April (Bajpai \& Chatuevedi, 1985). After fruit set it takes about 60 days for harvesting and mostly the fruits become ready for harvest at the end of the summer. Traditionally, jamun fruits, leaves, seeds and bark are used in ayurvedic medicine. The bark contains tannins and carbohydrates, accounting for its long term use as astringent to combat ailment like dysentery. A glycoside in the seed jamboline is considered to have antibiotic properties. The seeds also have anti-flammatory effects in rats and antioxidant properties in diabetic rat. Inspite of its greater economic value farmers are reluctant to establish jamun orchards as flowering is the major constraint. After planting of graft, it takes about 6 to 7 years for commencement of flowering. Many times this period is extended up to 10 years. Furthermore, flowering is sparse as a result fruit set and yield remains low. As per the preliminary experiment conducted to induce flowering in jamun by various treatments Viz. $\mathrm{KNO}_{3}$, paclobutrazol and ringing only later could induce flowering (Haldankar, Mukadam, \& Kadam, 2012). An experiment was therefore undertaken to study the efficiency of girdling in jamun under Maharashtra conditions.

\section{Material and Methods}

The experiment was conducted at two different locations with five treatments viz. $\mathrm{T}_{1}$ - Deep cut on secondary branches, $T_{2}$ - Deep cut on tertiary branches, $T_{3}$ - Removal of bark of $3 \mathrm{~mm}$ width on secondary branches $\mathrm{T}_{4}{ }^{-}$ 
Removal of bark of $3 \mathrm{~mm}$ width on tertiary branches and $\mathrm{T}_{5^{-}}$Control (No girdling). These five treatments were replicated four times with two plants per treatment per replication in Randomized Block Design during 2012-13. The details of two different geological locations are as follows.

Location A was at Pachora Dist. Jalgaon (M.S.), India, situated at $20^{\circ} 40^{\prime} 0$ " $\mathrm{N}$ latitudes and $75^{\circ} 21^{\prime} 0$ " $\mathrm{E}$ longitudes. The soil was medium black with hot and dry climate. Uniformly grown, 5 years old grafted plants of Jamun Var.Konkan Bahadoli were selected for experiment. The average height as well as spread of selected plants was $2.7 \mathrm{~m}$. Average circumference and breadth of secondary branches was $12.5 \mathrm{~cm}$ and $3.83 \mathrm{~cm}$ respectively, whereas average circumference and breadth of tertiary branches was $10.5 \mathrm{~cm}$ and $3.06 \mathrm{~cm}$ respectively.

Location B was at Konkangaon Dist. Nashik (MS) India, situated at $20^{\circ} 12^{\prime} 0^{\prime \prime} \mathrm{N}$ latitude and $73^{\circ} 49^{\prime} 59^{\prime \prime} \mathrm{E}$ longitudes. The soil was medium black with hot and dry climate. Uniformly grown, 7 years old grafted plants of Jamun Var.Konkan Bahadoli were selected for experiment. The average height and spread of selected plants was $3.65 \mathrm{~m}$ and $3.50 \mathrm{~m}$ respectively. Average circumference and breadth of secondary branches was $13.8 \mathrm{~cm}$ and 4.35 $\mathrm{cm}$ respectively, whereas average circumference and breadth of tertiary branches was $11.9 \mathrm{~cm}$ and $4.05 \mathrm{~cm}$ respectively.

The girdling as per the treatment details was done on 50 per cent branches of treated plants in first fortnight of October. Girdling was done by giving deep cut through the bark with knife without removal of bark in treatment $T_{1}$ and $T_{2}$ where as for treatments $T_{3}$ and $T_{4} 3 \mathrm{~mm}$ bark was completely removed. The observations viz. days for induction of flowering, flowering induced, inflorescence per square meter, number of flowers per twig, number of fruits per twig, days required for harvest, yield ( $\mathrm{kg} / \mathrm{plant}$ and $\mathrm{t} / \mathrm{ha}$ ) were recorded.

\section{Statistical Analysis}

The statistical analysis was performed as per the ANOVA suggested by Panse and Sukhatme (1997). The "P" value of data was estimated by students paired ' $t$ ' test. Standard Deviation was calculated as per the procedure advocated by Rangaswami (1995).

\section{Results and Discussion}

Table1. Effect of girdling on plants flowered (\%) and number of days required for flowering

\begin{tabular}{lllll}
\hline & \multicolumn{2}{c}{ Location A } & \multicolumn{2}{c}{ Location B } \\
\cline { 2 - 5 } Treatments & $\begin{array}{l}\text { Flowering } \\
\text { induced } \\
(\%)\end{array}$ & $\begin{array}{l}\text { No. of days required for } \\
\text { flowering after girdling }\end{array}$ & $\begin{array}{l}\text { Flowering } \\
\text { induced } \\
(\%)\end{array}$ & $\begin{array}{l}\text { No. of days required for } \\
\text { flowering after girdling }\end{array}$ \\
\hline $\begin{array}{l}\mathrm{T}_{1} \text { (Deep cut on secondary } \\
\text { branches) }\end{array}$ & 50 & $79.0^{\mathrm{c}}$ & 63 & $79.7^{\mathrm{c}}$ \\
$\mathrm{T}_{2}$ (Deep cut on tertiary & 100 & $\begin{array}{l}(79.0 \pm 3.46) \\
\left(75.25^{\mathrm{d}}\right.\end{array}$ & 75 & $75.0^{\mathrm{d}}$ \\
branches) & & $(75.25 \pm 2.50)$ & & $(75.0 \pm 2.16)$ \\
$\mathrm{T}_{3}$ (Removal of 3mm bark on & 50 & $85.5^{\mathrm{b}}$ & 50 & $85.0^{\mathrm{b}}$ \\
secondary branches) & & $(85.5 \pm 3.87)$ & & $(85.0 \pm 1.82)$ \\
$\mathrm{T}_{4}$ (Removal of 3mm bark on & 50 & $86.75^{\mathrm{b}}$ & 63 & $86.7^{\mathrm{b}}$ \\
tertiary branches) & & $(79.0 \pm 3.30)$ & & $(86.7 \pm 3.40)$ \\
$\mathrm{T}_{5}$ (control) & 50 & $97.0 \mathrm{a}$ & 25 & $98.0^{\mathrm{a}}$ \\
& & $(97.0 \pm 3.41)$ & & $(98.0 \pm 2.16)$ \\
$\mathrm{S.E} \pm$ & - & 0.93 & - & 0.88 \\
$\mathrm{CD}$ @5\% & - & 2.74 & - & 2.85 \\
$\%$ P value & - & 0.00000192 & - & 0.000024 \\
\hline
\end{tabular}

The girdling treatments influenced the flowering and days required for flowering after girdling in Jamun (Table 1). At both locations, $T_{2}$ contributed for flowering in maximum plants $(100 \%$ and $75 \%)$. $T_{1}$ and $T_{4}$ contributed for 50 per cent flowering at location A and 63 per cent flowering at location B. It was followed by $\mathrm{T}_{3}$ where 50 
percent plants flowered at both locations. Only 25 per cent plants in $T_{5}$ (Control) could produce flowers at location B and 50 per cent at location A. After the exposure of treatments, earliest flowering was recorded in $\mathrm{T}_{2}$ at location A (75.25 days) and location B (75.00 days). It was followed by $\mathrm{T}_{1}$ where plants flowered after 79 days at location A and 79.7 days at location B. It took 85.5 days and 85.0 days for flowering respectively at location A and $\mathrm{B}$ in $\mathrm{T}_{3}$. It was followed by $\mathrm{T}_{4}$. In control, the flowering started after 97 days at Location $\mathrm{A}$ and 98 days at Location B after commencement of experiment. Girdling stop the besipetal movement of assimilates through phloem which results in accumulation of carbohydrates and plant hormones above the girdle (Roper \& Williams, 1989; Schaper \& Chacko, 1993; Amar Singh, 2003; Urban \& Alphonsout, 2006). Transitory block of phloem flux apparently increases sugar availability in the aerial parts of tree which induced flowering in citrus (Wallerstein, Goren, \& Ben-Tal, 1978; Yamanishi, 1995). The results indicated that girdling improved flowering in Jamun with reduced number of days required for flowering in treated plants as compared to control. Tertiary branches were found to be better for girdling than secondary branches. Girdling with deep cut without removal of bark was more beneficial than the removal of bark.

Table 2. Effect of girdling on flowering intensity (\%), flowers per twig and days required from flowering to harvesting

\begin{tabular}{|c|c|c|c|c|c|c|}
\hline \multirow[b]{2}{*}{ Treatments } & \multicolumn{3}{|l|}{ Location A } & \multicolumn{3}{|l|}{ Location B } \\
\hline & $\begin{array}{l}\text { Inflorescence } \\
\text { Per } \mathrm{m}^{2}(\%)\end{array}$ & $\begin{array}{l}\text { Flowers per } \\
\text { twig }\end{array}$ & $\begin{array}{l}\text { Days required - } \\
\text { flowering to } \\
\text { harvesting }\end{array}$ & $\begin{array}{l}\text { Inflorescence } \\
\text { Per m }^{2}(\%)\end{array}$ & $\begin{array}{l}\text { Flowers per } \\
\text { twig }\end{array}$ & $\begin{array}{l}\text { Days required } \\
\text { - flowering to } \\
\text { harvesting }\end{array}$ \\
\hline $\begin{array}{l}\mathrm{T}_{1} \text { (Deep cut } \\
\text { on secondary } \\
\text { branches) }\end{array}$ & $\begin{array}{l}55.0^{\mathrm{b}} \\
(55.0 \pm 12.90)\end{array}$ & $\begin{array}{l}29.0^{\mathrm{b}} \\
(29.0 \pm 6.92)\end{array}$ & $\begin{array}{l}123.0^{\mathrm{b}} \\
(123.0 \pm 11.22)\end{array}$ & $\begin{array}{l}47.5^{\mathrm{a}} \\
(47.5 \pm 20.61)\end{array}$ & $\begin{array}{l}33^{\mathrm{b}} \\
(33 \pm 11.48)\end{array}$ & $\begin{array}{l}125.0^{\mathrm{ab}} \\
(125.0 \pm 12.90 \\
)\end{array}$ \\
\hline $\begin{array}{l}\mathrm{T}_{2} \text { (Deep cut } \\
\text { on tertiary } \\
\text { branches) }\end{array}$ & $\begin{array}{l}67.5^{\mathrm{b}} \\
(67.5 \pm 9.57)\end{array}$ & $\begin{array}{l}40.5^{\mathrm{a}} \\
(40.5 \pm 12.47)\end{array}$ & $\begin{array}{l}120.5^{\mathrm{b}} \\
(120.5 \pm 6.13)\end{array}$ & $\begin{array}{l}55.0^{\mathrm{a}} \\
(55.0 \pm 12.90)\end{array}$ & $\begin{array}{l}43^{\mathrm{a}} \\
(43 \pm 8.24)\end{array}$ & $\begin{array}{l}120.0^{\mathrm{ab}} \\
(120.0 \pm 5.71)\end{array}$ \\
\hline $\begin{array}{l}\mathrm{T}_{3} \text { (Removal } \\
\text { of } 3 \mathrm{~mm} \text { bark } \\
\text { on secondary } \\
\text { branches) }\end{array}$ & $\begin{array}{l}52.5^{\mathrm{b}} \\
(52.5 \pm 9.57)\end{array}$ & $\begin{array}{l}21.0^{\mathrm{c}} \\
(21.0 \pm 5.03)\end{array}$ & $\begin{array}{l}128.0^{\mathrm{b}} \\
(128.0 \pm 6.97)\end{array}$ & $\begin{array}{l}30.0^{\mathrm{b}} \\
(30.0 \pm 8.16)\end{array}$ & $\begin{array}{l}14^{\mathrm{a}} \\
(14 \pm 6.92)\end{array}$ & $\begin{array}{l}128.25^{\mathrm{a}} \\
(128.25 \pm 6.94\end{array}$ \\
\hline $\begin{array}{l}\mathrm{T}_{4} \text { (Removal } \\
\text { of } 3 \mathrm{~mm} \text { bark } \\
\text { on tertiary } \\
\text { branches) }\end{array}$ & $\begin{array}{l}45.0^{\mathrm{b}} \\
(45.0 \pm 5.77)\end{array}$ & $\begin{array}{l}28.0^{\mathrm{b}} \\
(28.0 \pm 4.61)\end{array}$ & $\begin{array}{l}130.5^{\mathrm{a}} \\
(130.5 \pm 9.81)\end{array}$ & $\begin{array}{l}37.5^{\mathrm{ab}} \\
(37.5 \pm 17.07)\end{array}$ & $\begin{array}{l}33^{\mathrm{b}} \\
(6.5 \pm 1.91)\end{array}$ & $\begin{array}{l}131.0^{\mathrm{a}} \\
(131.0 \pm 9.48)\end{array}$ \\
\hline $\mathrm{T}_{5}$ (control) & $\begin{array}{l}45.0^{\mathrm{b}} \\
(45.0 \pm 12.9)\end{array}$ & $\begin{array}{l}18.0^{\mathrm{c}} \\
(18.0 \pm 2.30)\end{array}$ & $\begin{array}{l}140.0^{\mathrm{a}} \\
(123.0 \pm 11.54)\end{array}$ & $\begin{array}{l}17.50^{\mathrm{b}} \\
(17.50 \pm 5.0)\end{array}$ & $\begin{array}{l}12^{\mathrm{c}} \\
(12.0 \pm 5.65)\end{array}$ & $\begin{array}{l}137.5^{\mathrm{a}} \\
(137.5 \pm 9.57)\end{array}$ \\
\hline S.E \pm & 3.69 & 2.20 & 3.41 & 5.32 & 3.3 & 3.46 \\
\hline CD@5\% & 10.78 & 6.44 & 9.97 & 15.7 & 9.8 & 10.10 \\
\hline$\% \mathrm{P}$ value & 0.0013 & 0.0000021 & 0.0047 & 0.0014 & 0.000018 & 0.0199 \\
\hline
\end{tabular}

Inflorescence and number of flowers per twig was improved by girdling (Table 2). The maximum inflorescence and number of flowers per twig were recorded in $\mathrm{T}_{2}$ at both locations (i.e. Location $\mathrm{A}$ and $\mathrm{B}$ ). It was followed by $T_{1}$. The flowers per twig produced in $T_{4}$ were greater than $T_{3}$ at both locations. Importantly, minimum magnitude for inflorescence and number of flowers per twig was found in $\mathrm{T}_{5}$ at both locations. The duration from flowering to harvesting was reduced by girdling as compared to Control $\left(T_{5}\right)$. This period was shortest in $T_{2}$ followed by $T_{1}$, $\mathrm{T}_{3}$ and $\mathrm{T}_{4}$ at both locations. The substantial increase in flowering by girdling was also reported in mango (Gaskins, 1963) and apple (Samad, 1998). In apple, girdling was found to increase inflorescence development (Arakawa, Kanno, Kanetsuka, \& Shiozaki, 1997). The fruit growth was enhanced by girdling in Syzygium samarangense (Khandakar, Abm, Normaniza, \& Amru, 2011). 
Table 3.Effect of girdling on fruits per twig, yield (kg/plant) and yield (t/ha)

\begin{tabular}{|c|c|c|c|c|c|c|}
\hline \multirow[b]{2}{*}{ Treatments } & \multicolumn{3}{|l|}{ Location A } & \multicolumn{3}{|l|}{ Location B } \\
\hline & $\begin{array}{l}\text { No. of fruits } \\
\text { per twig }\end{array}$ & $\begin{array}{l}\text { Yield } \\
\text { (Kg/plant) }\end{array}$ & Yield(t/ha) & $\begin{array}{l}\text { No. of fruits per } \\
\text { twig }\end{array}$ & $\begin{array}{l}\text { Yield } \\
\text { (Kg/plant) }\end{array}$ & Yield (t/ha) \\
\hline $\begin{array}{l}\mathrm{T}_{1} \text { (Deep cut on } \\
\text { secondary } \\
\text { branches) }\end{array}$ & $\begin{array}{l}5.5^{\mathrm{a}} \\
(5.5 \pm 1.91)\end{array}$ & $\begin{array}{l}28^{\mathrm{b}} \\
(28 \pm 4.61)\end{array}$ & $\begin{array}{l}13.82^{b} \\
(13.82 \pm 2.28)\end{array}$ & $\begin{array}{l}6.0^{\mathrm{a}} \\
(6.0 \pm 1.63)\end{array}$ & $\begin{array}{l}32.0^{\mathrm{b}} \\
(32.0 \pm 9.79)\end{array}$ & $\begin{array}{l}15.78^{\mathrm{b}} \\
(15.78 \pm 4.82)\end{array}$ \\
\hline $\begin{array}{l}\mathrm{T}_{2} \text { (Deep cut on } \\
\text { tertiary } \\
\text { branches) }\end{array}$ & $\begin{array}{l}6.0^{\mathrm{a}} \\
(6.0 \pm 1.63)\end{array}$ & $\begin{array}{l}37^{\mathrm{a}} \\
(37.0 \pm 7.57)\end{array}$ & $\begin{array}{l}18.25 \mathrm{a} \\
(18.25 \pm 3.74)\end{array}$ & $\begin{array}{l}6.5^{\mathrm{a}} \\
(6.5 \pm 1.0)\end{array}$ & $\begin{array}{l}39.0^{\mathrm{a}} \\
(39.0 \pm 6.83)\end{array}$ & $\begin{array}{l}19.22^{\mathrm{a}} \\
(19.22 \pm 3.38)\end{array}$ \\
\hline $\begin{array}{l}\mathrm{T}_{3} \text { (Removal of } \\
3 \mathrm{~mm} \text { bark on } \\
\text { secondary } \\
\text { branches) }\end{array}$ & $\begin{array}{l}3.5^{\mathrm{b}} \\
(3.5 \pm 1.0)\end{array}$ & $\begin{array}{l}24^{\mathrm{b}} \\
(24 \pm 6.53)\end{array}$ & $\begin{array}{l}11.85^{\mathrm{b}} \\
(11.85 \pm 3.22)\end{array}$ & $\begin{array}{l}4.5^{\mathrm{b}} \\
(4.5 \pm 1.0)\end{array}$ & $\begin{array}{l}27.0^{\mathrm{b}} \\
(27.0 \pm 3.82)\end{array}$ & $\begin{array}{l}13.32^{\mathrm{b}} \\
(13.32 \pm 1.89)\end{array}$ \\
\hline $\begin{array}{l}\mathrm{T}_{4}(\text { Removal of } \\
3 \mathrm{~mm} \text { bark on } \\
\text { tertiary } \\
\text { branches })\end{array}$ & $\begin{array}{l}4.5^{\mathrm{ab}} \\
(4.5 \pm 1.0)\end{array}$ & $\begin{array}{l}26^{\mathrm{b}} \\
(26 \pm 4.0)\end{array}$ & $\begin{array}{l}12.82^{\mathrm{b}} \\
(12.82 \pm 1.98)\end{array}$ & $\begin{array}{l}5.0^{\mathrm{ab}} \\
(5.0 \pm 1.15)\end{array}$ & $\begin{array}{l}28.0^{\mathrm{b}} \\
(28.0 \pm 4.61)\end{array}$ & $\begin{array}{l}13.82^{\mathrm{b}} \\
(13.82 \pm 2.28)\end{array}$ \\
\hline $\mathrm{T}_{5}$ (control) & $\begin{array}{l}3.0^{\mathrm{b}} \\
(3.0 \pm 1.15)\end{array}$ & $\begin{array}{l}22.5^{\mathrm{b}} \\
(22.5 \pm 1.91)\end{array}$ & $\begin{array}{l}11.11^{\mathrm{b}} \\
(11.11 \pm 0.94)\end{array}$ & $\begin{array}{l}3.5^{\mathrm{b}} \\
(3.5 \pm 1.0)\end{array}$ & $\begin{array}{l}26.0^{\mathrm{b}} \\
(26.0 \pm 4.0)\end{array}$ & $\begin{array}{l}12.83^{\mathrm{b}} \\
(12.83 \pm 1.97)\end{array}$ \\
\hline S.E \pm & 0.40 & 2.03 & 1.00 & 0.44 & 2.30 & 1.13 \\
\hline CD@5\% & 1.17 & 5.94 & 2.93 & 1.30 & 6.79 & 3.35 \\
\hline$\% \mathrm{P}$ value & 0.000066 & 0.00034 & 0.00036 & 0.0017 & 0.0083 & 0.0088 \\
\hline
\end{tabular}

Girdling improved number of fruits per twig and yield in jamun at both locations (Table 3). $\mathrm{T}_{2}$ was the best treatment which contributed for maximum number of fruits per twig and yield $(\mathrm{kg} / \mathrm{plant}$ and $\mathrm{t} / \mathrm{ha})$. It was followed by $T_{1}, T_{4}$ and $T_{3}$. The minimum number of fruits per twig as well as yield was recorded in $T_{5}$. This can be attributed to more number of flowers due to girdling contributing more fruits and yield in treated plants. Girdling was found to increase fruit set and yield in wax apple (Minh \& Chung, 2012), apple (Samad, 1998), Litchi (Li \& Xiao, 2001) and peach (Allen, George, Nissen, \& Rasmussen, 1993).

Thus, the present investigation revealed the benefits of girdling in jamun for induction of flowering, greater number of inflorescence, more number of fruits per twig and higher yield than control plants under two agro climatic conditions. Tertiary branches were found to be more appropriate location for girdling than secondary branches. Girdling with deep cut without removal of bark was more beneficial than the removal of bark which indicates its efficiency to accumulate sufficient carbohydrates for flower induction. The faster healing thereafter resulted into higher fruit set and yield.

\section{Conclusion}

It was concluded that the girdling in jamun by giving deep cut on 50 percent tertiary branches in the month of October contributed to induce flowering with more inflorescence, more number of flowers and fruits per twig and higher yield.

\section{Acknowledgement}

We sincerely wish to thank Mr. R.O. Patil, A/P- Pachora, Dist. Jalgaon (MS) India and Mr. S.M. Tidke, A/PKokangaon Dist. Nasik (MS) India for providing their jamun orchards and necessary help for conducting these experiments.

\section{References}

Allen, P., George, A. P., Nissen, R. J., \& Rasmussen, T. S. (1993). Effect of girdling time on growth, yield, and fruit maturity of the low chill peach cultivar Flordaprince. Aust. J. Exp. Agr., 33(6), 781-785. http://dx.doi.org/10.1071/EA9930781 
Amar Singh. (2003). Fruit physiology and production (p. 195). Ludhiana: Kalyani Publishers.

Arakawa, O. K., Kanno, Kanetsuka, A., \& Shiozaki, Y. (1997). Effect of girdling and barj inversionon tree growth and fruit quality of apple. Proc. Int. Symp. Integ. Canopy. Acta Hortic, 451, 579-586.

Bajpai, P. N., \& Chaturvedi, O. P. (1985). Fruits of India: Tropical and Subtropical (p. 586). Culcutta: Naya Prokash.

Gaskin, M. H. (1963). Girdling mango seedlings for inducing early fruit bearing. Florida State Horticultural Society, 360-363

Haldankar, P. M., Mukadam, S. J., \& Kadam, S. G. (2012). Induction of flowering in jamun (Syzygium cuminii L.)Abstract submitted in 5 th Indian Horticultural Congress - An International Meet held from November 6 -9, 2012 at Punjab Agriculture University Ludhiana p. 27.

Li, C. B., \& Xiao, Y. (2001). Girdling increases yield of Nuomici litchi. Proc.I Int. Symp. H. Huang \& C. Menzel (Eds.). Acta Hort, 558, 233.

Khandakar, M. M., Abm, S. H., Normaniza, O., \& Amru, N. B. (2011). Application of girdling for improved fruit retention, yield and fruit quality on Syzygium samarangensis under field conditions. Int. J. Agric. Biol, 13, $18-24$.

Minh, T. N., \& Chung, R. Y. (2012). Effect of S- Girdling on fruit growth and fruit quality of wax apple. World Academy of Science, Engineering and Technology, 72, 216.

Panse, V. G., \& Sukhatme, P. V. (1997). Statistical methods for agricultural workers. ICAR Rev. In P. V. Sukhatme \& V. N. Amble (Eds.). pp. 97-156.

Rangaswamy, R. (1995). Textbook of agricultural statistics (2nd ed.). New Age International Publishers.

Roper, R. T., \& Williams, L. (1989). Net $\mathrm{CO}_{2}$ assimilation and carbohydrate partitioning of grape vine leaves in response to trunk girdling and gibberelic acid application. Plant Physiol, 89, 1136-1140. http://dx.doi.org/10.1104/pp.89.4.1136

Samad, A. (1998). Effect of girdling and bridge grafting on apple tree growth, yield, apple quality and biochemical composition for apple trees growing under moderate and ultra high density conditions. A Ph.D. thesis submitted to Lincoln University.

Schaper, H., \& Chacko, E. K. (1993). Effect of irradiance, leaf age, chlorophyll content and branch girdling on gas exchange of cashew (Anacardium occidentale L.) leaves. J.Hortic. Sci, 68, 541-550.

Urban, L., \& Alphonsout, L. (2006). Girdling decreases photosynthetic electron fluxes and induces sustained photoprotection in mango leaves, Tree Physiology, 27, 345-352. http://dx.doi.org/10.1093/treephys/27.3.345

Wallerstein, I., Goren, R., \& Ben-Tal, Y. (1978). Effect of ringing on root starvation in sour orange seedling. $J$. Hort. Sci, 53, 109-113.

Yamanishi, O. K. (1995). Trunk strangulation and winter heating effects on fruit size, internal quality and maturation of Tosa Buntan pummel grown in a plastic house. J. Hort.Sci, 70, 65-74.

\section{Copyrights}

Copyright for this article is retained by the author(s), with first publication rights granted to the journal.

This is an open-access article distributed under the terms and conditions of the Creative Commons Attribution license (http://creativecommons.org/licenses/by/3.0/). 